African Crop Science Journal by African Crop Science Society is licensed under a Creative Commons Attribution 3.0 Uganda License. Based on a work at www.ajol.info/ and www.bioline.org.br/cs DOI: https://dx.doi.org/10.4314/acsj.v29i1.9

\title{
EFFICACY OF SPRAYING INTERVALS OF RIDOMIL PLUS 66 WP FOR CONTROL OF TARO LEAF BLIGHT DISEASE
}

\author{
J. ADOMAKO, N.E. AMENGOR, S. LARBI-KORANTENG ${ }^{1}$ and F. KANKAM ${ }^{2}$
}

CSIR-Crops Research Institute, Plant Health Division, P. O. Box 3785, Kumasi, Ghana

${ }^{1}$ University of Education, Winneba, Department of Crop and Soil Science Education, AsanteMampong, Ghana

${ }^{2}$ University for Development Studies, Department of Agronomy, Tamale, Ghana

Corresponding author: joeadomako@gmail.com

(Received 27 January 2020; accepted 22 January 2021)

\begin{abstract}
Taro leaf blight causes up to $100 \%$ yield loss in susceptible taro (Colocasia esculenta L. (Schott)) cultivars. The use of fungicides in disease management is fast and effective; however efficacy of fungicides could be affected by frequency of application. The objective of this study was to evaluate the efficacy of spraying intervals and economic benefits of Ridomil Plus 66 WP (12\% Metalaxyl-M and $60 \%$ Copper (1) oxide) on taro leaf blight disease. The study consisted of four fungicide spraying intervals, viz at one, two and at four weekly intervals, all at the concentration of $3.3 \mathrm{~g} \mathrm{l}^{-1}$ and no fungicide application as the control. Results showed no significant differences $(\mathrm{P}>00.5)$ between one and two weekly spraying intervals in terms of taro leaf blight disease incidence and severity. These were, however, significantly different $(\mathrm{P}<0.05)$ from four weekly and no fungicide applications. Taro corm yield was higher in weekly spraying interval, but not significantly different $(P>0.05)$ from biweekly application intervals. Yields in weekly intervals were 2.9,33.0 and 44.0\% higher than biweekly, four weekly and no application intervals. Applying fungicide at a biweekly interval was found to be economically efficient as it recorded higher total revenue and net present values. Applying $66 \mathrm{WP}$ (12\% Metalaxyl-M and 60\% Copper (1) oxide) at 2 weekly interval was the optimum period and most efficient to reduce the incidence and severity of Phytophthora leaf blight disease and increase yield of taro.
\end{abstract}

Key Words: Benefit-cost ratio, Colocasia esculenta, disease severity, fungicide spraying intervals, yield

\section{RÉSUMÉ}

La brûlure des feuilles de taro peut causer une perte de rendement allant jusqu'à $100 \%$ chez les cultivars sensibles de taro (Colocasia esculenta L. (Schott)). L'utilisation de fongicides dans la gestion des maladies est rapide et efficace; cependant, l'efficacité des fongicides pourrait être affectée par la fréquence d'application. L'objectif de cette étude était d'évaluer l'efficacité des intervalles de 
pulvérisation et les avantages économiques de Ridomil Plus 66 WP (12\% de métalaxyl-M et $60 \%$ d'oxyde de cuivre (1)) sur la maladie du taro. L'étude consistait en quatre intervalles de pulvérisation de fongicide, c'est-à-dire à une, deux, quatre intervalles hebdomadaires, le tout à la concentration de $3,3 \mathrm{~g} \mathrm{l}^{-1}$ et sans application de fongicide. Les résultats n'ont montré aucune différence significative (P> $00,5)$ entre un et deux intervalles de pulvérisation hebdomadaires en termes d'incidence et de gravité de la brûlure du taro. Celles-ci étaient cependant significativement différentes $(P<0,05)$ de quatre applications hebdomadaires et sans fongicide. Le rendement en corme de taro était plus élevé dans l'intervalle de pulvérisation hebdomadaire, mais pas significativement différent $(\mathrm{P}>0,05)$ des intervalles d'application bihebdomadaires. Les rendements à intervalles hebdomadaires étaient de 2,9, 33,0 et $44,0 \%$ supérieurs à ceux des deux semaines, quatre semaines et aucun intervalle d'application. L'application d'un fongicide toutes les deux semaines s'est avérée être économiquement efficace car elle a enregistré des revenus totaux et des valeurs actuelles nettes plus élevés. En conclusion, l'application de 66 WP (oxyde de métalaxyl-M à $12 \%$ et oxyde de cuivre (1) à 60\%) à intervalles de 2 semaines s'est avérée être la période optimale et la plus efficace pour réduire l'incidence et la gravité de la maladie phytophthora et augmenter le rendement du taro .

Mots Clés: rapport avantages-coûts, Colocasia esculenta, gravité de la maladie, intervalles de pulvérisation de fongicide, rendement

\section{INTRODUCTION}

Taro (Colocasia esculenta L. (Schott)) is an important staple in different parts of the world. It is a rich source of carbohydrates, proteins, minerals and vitamins (Nath et al., 2013). In addition, the corms are used for the production of high fructose syrup and alcohol (Misra et $a l ., 2008)$. Production of the crop is, however, constrained by high incidence of leaf blight disease, caused by Phytophthora colocasiae Raciborski; the most destructive disease infecting the crop in major producing countries (Gadre and Joshi, 2003). The disease accounts for corm yield loss of up to $50 \%$ (Singh et al., 2006) and leaf yield loss of $95 \%$ in susceptible varieties (Nelson et al., 2011). In several communities where there have been outbreaks of the disease, farmers sometimes abandon fields or rotate with other staple crops.

Several strategies have been employed to manage taro leaf blight disease; however, judicious use of fungicide is the fastest and most effective method. Mancozeb, metalaxyl and phosphorus acid based fungicides have successfully been used to control taro leaf blight disease (Maheswari et al., 2001). Reduction in severity of taro leaf blight disease and increase in yield of corm/cormels was observed following application of Ridomil Gold MZ 68 WG (Mefonoxam 4\% + Mancozeb 64\%) (Maheswari et al., 2001). The efficacy of fungicides to manage the disease in taro production can, however, be affected by frequency of application (Manju et al., 2017). Application of Fungiforce (Metalaxyl 12\% + Copper Oxide 60\%) forthnightly, according to Manju et al. (2017), was more effective in managing taro leaf blight disease, contradicting Tarla et al. (2014), who found no differences in taro leaf blight disease incidence and severity following Plantomil 72 WP (Copper oxide (60\%) and Metalaxyl (12\%) application at different spray intervals. Using the recommended fungicide concentration should correspond with spraying intervals to achieve maximum efficacy. The objective of this study was to evaluate the efficacy of spraying intervals and economic benefits of Ridomil Plus 66 WP (12\% Metalaxyl-M and 60\% Copper (1) oxide) on taro leaf blight disease on taro.

\section{MATERIALS AND METHODS}

Study area. Field experiments were conducted on a taro leaf blight naturally infected fields at Kwamo (N06 ${ }^{\circ} 43.098^{\prime}$ W001 $^{\circ}$ 
$29.727^{\prime}$ ) in the Ejisu Municipality of Ghana in 2016 and 2017, between April and September of each year. The area falls within the semideciduous forest zone of Ghana, and experiences a bimodal rainfall pattern (Amekudzi et al., 2015). The major rains usually commences in late March to early April until mid-July, followed by a short dry season from mid-July to the end of August. This is followed by the minor rainy season that begins from September to early November and ushers in the long dry season.

Soil in the area, according to AdjeiGyapong and Asiamah (2000), supports production of taro. The field had naturally infected taro plants with $P$. colocasiae and was, therefore, considered a hotspot of the disease.

A taro leaf blight susceptible landrace obtained from farmer field was used for the study. Prior to the field experiment, taro suckers were washed under running water to remove soil.

The experiment consisted of four treatments, viz fungicide application at one, two and four weekly intervals; and with no fungicide application (control), after the appearance of disease symptoms. For the one week interval application, a total of 14 applications were made, while eight and four applications were made for two and four weekly application intervals. The fungicide was applied at the recommended rate of $3.3 \mathrm{~g} \mathrm{l}^{-1}$.

The experiment was laid out in randomised complete block design with three replicates. Cost-Benefit analysis was used to determine the viability of the various chemical application regimes employed in the study (Shively and Galopin, 2013)

Data collection and analysis. Two year data (2016 and 2017) were pool together prior to data analysis. Disease parameters, namely incidence (\% of plants infected) and disease severity (proportion of leaf area with lesions) were assessed on ten central row plants at 12 , 16, 20, 24 and 28 weeks after planting. To assess disease severity, taro leaves were rated on a scale of $0-5$ (0-healthy leaves, $1-<1 \%$ infection, $2-1.0-5.0 \%$ infection, $3-5.01-25 \%$ infection, 4-25.01-50\% infection and 5->50\% infection). The area under severity index progress (AUSIP) was calculated using the formula as described by (Shaner and Finney, 1977) as follows:

$$
\sum_{t=1}^{n}(D s 1+D s 2 / 2) x(t 2-t 1)
$$

Where:

Ds1 is disease severity recorded in time 1; Ds2 is disease severity recorded in time $2, \mathrm{t} 1$ and t2 are times (number of days) for observations; $\mathrm{n}$ is number of observations.

To determine yield of the plants, ten taro stands in the central row of each plot were harvested at seven months after planting, and their yields recorded as weight of taro corm per area harvested. Mean disease incidence and severity index data were arcsine transformed in order to homogenise the variances. Disease incidence, severity and yield data were subjected to the analysis of variance (ANOVA) and the mean effects separated by Standard Error Differences (SED) method at $5 \%$ level of probability, using GenStat Discovery version 12.0 (VSN International).

Economic analysis (Cost-Benefit Analysis approach) was employed to determine the viability of various application intervals employed in the study. The Cost Benefit analysis model estimates and compares all relevant costs and benefits of the economic, environmental and social impacts of an intervention, expressed in monetary value base on available information. In this context, chemical application regimes involved costs of chemicals and their application at different times. Total cost, therefore, varied across different application regimes. Benefits on the other hand, hinged on revenue, which is informed by the yield per hectare obtain under each treatment and the prices at which they were sold. In order that the effect of yield 
difference is well enumerated, general prices from the Kumasi Central Market, Kumasi, Ghana, formed the bases for computing revenue and other benefit indicators. Two approaches were employed in determining the most economical chemical application regime, namely the Net Present Value (NPV) and the Benefit-Cost Ratio (BCR). The net present value (NPV) is the difference between the present value of the costs and the present value of the benefits:

$N P V=P V(B)-P V(C)$

Where:

$\mathrm{B}=$ Benefits and $\mathrm{C}=$ Costs, When NPV is greater than zero, then the application interval is worth employing.

A high NPV indicates the most efficient and economic application interval. The benefit cost ratio (BCR) is the ratio of the present value of benefits and the present value of costs given as:

$$
B C R=\frac{P V(B)}{P V(C)}
$$

The benefit-cost ratio shows the overall value for money for employing a particular fungicide application frequency. If the ratio is greater than 1, the application interval is acceptable (Shively and Galopin, 2013). The cost benefit analysis model was constructed using Microsoft EXCEL software (Shively and Galopin, 2013).

\section{RESULTS}

Disease incidence. Applying Ridomil Plus 66 WP at different intervals reduced taro leaf blight disease incidence. At 12 weeks after planting, the highest disease incidence of $24.9 \%$ was recorded in four weekly fungicide spraying interval. This was significantly different from $19.3 \%$ recorded for the other treatments. Sixteen weeks after planting, disease incidence in weekly and biweekly spraying intervals were significantly lower $(\mathrm{P}<0.05)$ than the control and four weekly fungicide application intervals (Fig. 1). Subsequently, at $20 \mathrm{WAP}$, the highest disease incidence of $58.6 \%$ was recorded in control plots which was significantly different from all Ridomil Plus 66 WP treated plots (Fig. $1)$.

Disease severity. At 12 WAP, the control plot recorded the lowest disease severity compared to Ridomil Plus 66 WP treated plots (Table 1). The control plot recorded the highest mean disease severity of 67.5 compared to 43.7 recorded in 1 weekly spraying interval (Table 1). Generally, disease severity in the control plot was $54.4,47.7$ and $4.7 \%$ more than in 1 , 2 and 4 weekly spraying intervals (Table 1 ). Highest mean disease severity of 69.6 was recorded at 24 WAP, while the lowest mean disease severity of 33.1 was recorded at 12 WAP (Table 1). Throughout the study, no significant differences were observed between four weekly fungicide application and the control, but each was significantly different from 1 and biweekly fungicide applications from 16 WAP (Table 1). Spraying Ridomil Plus $66 \mathrm{WP}$ at one and two weekly intervals were not significantly different throughout the study.

Area Under Severity Index Progress Curve (AUSIPC). Spraying fungicide at weekly and biweekly intervals reduced AUSIPC value compared to no fungicide application (Fig. 2). The highest AUSIPC of 439.8 was recorded for control plots compared to 313.2 recorded in weekly spraying interval. Significant differences $(\mathrm{P}<0.05)$ in AUSIPC were observed between all the treatments applied (Fig. 2).

Yield assessment. Applying Ridomil Plus 66 WP at a weekly interval recorded yield of $3.6 \mathrm{tha}^{-1}$ which was significantly different $(\mathrm{P}$ $<0.05$ ) from $2.5 \mathrm{t} \mathrm{ha}^{-1}$ recorded in control plots (Table 2). Similarly, significant difference $(\mathrm{P}<0.05)$ were observed between biweekly spraying interval and control plots as well as 


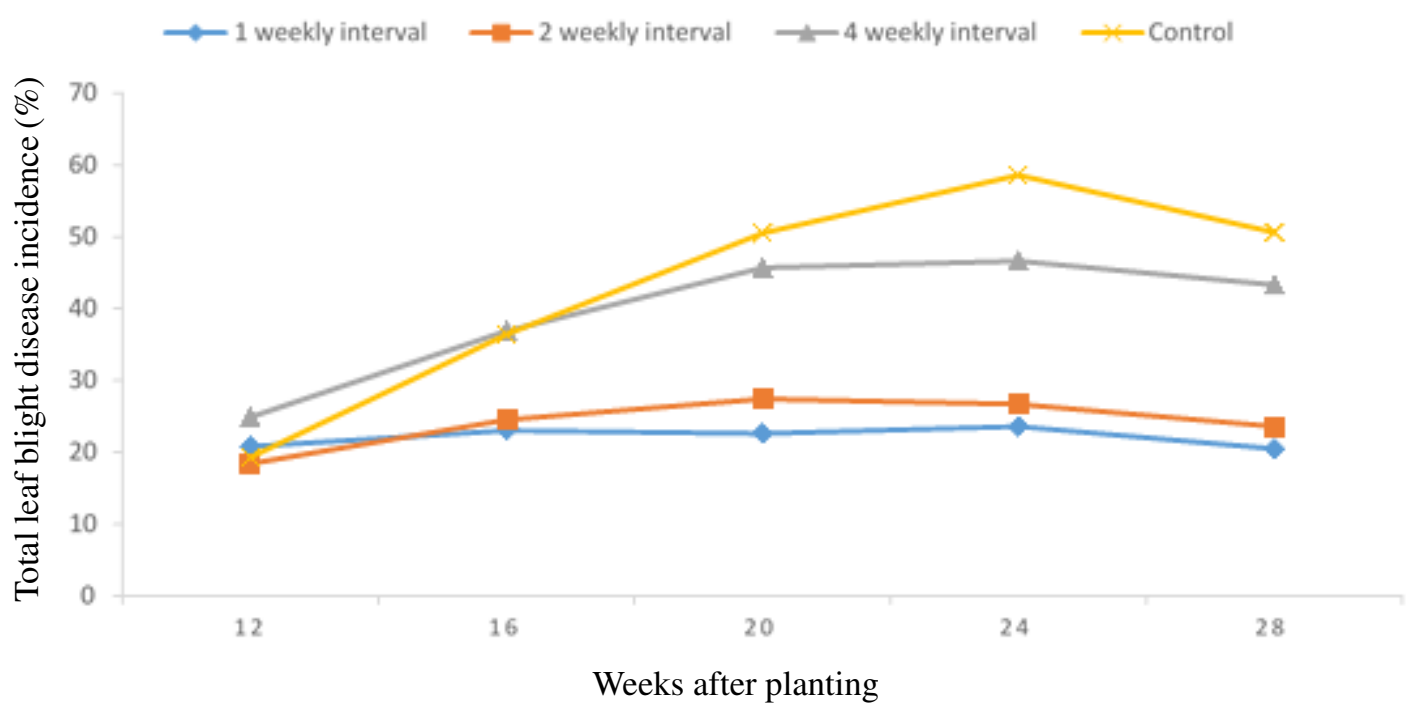

Figure 1. Taro leaf blight disease incidence at different times after planting, following fungicide application at different intervals.

TABLE 1. Taro leaf blight disease severity index at different weeks after planting following Ridomil Plus 66 WP application at different periods

\begin{tabular}{|c|c|c|c|c|c|c|}
\hline \multirow[t]{2}{*}{ Spraying interval } & \multicolumn{5}{|c|}{ Mean disease severity index at different weeks after planting } & \multirow[t]{2}{*}{ Mean } \\
\hline & 12 & 16 & 20 & 24 & 28 & \\
\hline 1 & 33.0 & 45.5 & 48.7 & 47.8 & 43.5 & 43.7 \\
\hline 2 & 33.3 & 46.1 & 51.0 & 50.7 & 46.8 & 45.7 \\
\hline 4 & 33.3 & 48.8 & 65.4 & 90.0 & 85.3 & 64.5 \\
\hline Control & 32.6 & 48.6 & 80.1 & 90.0 & 86.0 & 67.5 \\
\hline Mean & 33.1 & 47.1 & 61.3 & 69.6 & 65.4 & 55.3 \\
\hline SED & 3.8 & 2.5 & 6.5 & 1.7 & 3.6 & \\
\hline
\end{tabular}

Data on the severity index was arcsine transformed before analysis.

four weekly application of Ridomil Plus 66 WP (Table 2). Applying the fungicide at weekly spraying interval was, however, not significantly different from biweekly spraying interval.

Economic analysis. From the cost benefit ratio analysis, total cost and revenue of $\mathrm{GH} \phi 570.00$ (\$96.86) and $\mathrm{GH} \varnothing 1650.00$ (\$280.37), respectively, were recorded in 1 week spray interval compared to all the other spraying intervals. With respect to net present value, 2 weeks spray interval recorded the highest value of $\mathrm{GH} \varnothing 1,210.0$ (\$205.61) compared to $\mathrm{GH} \not 835.0$ (\$141.89) recorded for 4 weeks spray interval. Comparing the spraying intervals, it was observed that fungicide applications at 2 weeks interval was more beneficial than spraying weekly or every four weeks. A benefit-cost ratio of 4.10 was recorded in 2 weeks spraying interval compared to 2.89 and 3.75 recorded for weekly 


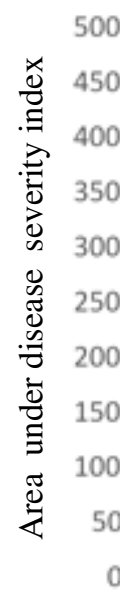

50
400
50
00
50
00
50
00
50
0
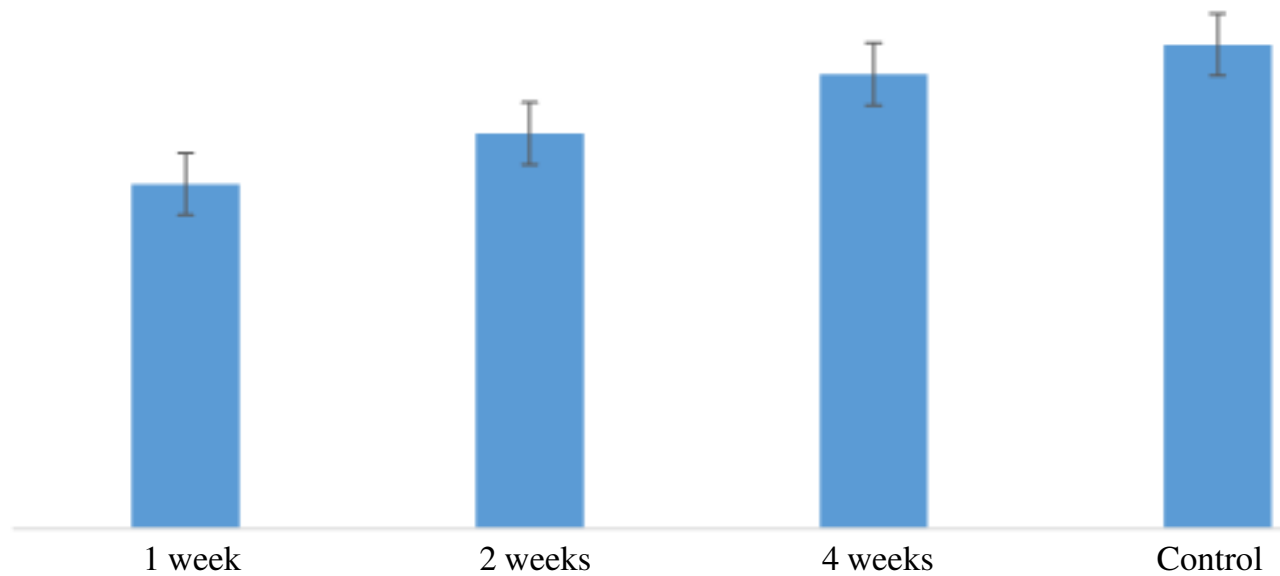

Ridomil Plus 66 WP spraying intervals

Figure 2. Area under disease progress curve using disease severity index following different application frequency of Ridomil Plus 66 WP fungicide.

TABLE 2. Effect of Ridomil Plus 66 WP applied at different weeks on yield of taro corm $\left(\mathrm{t} \mathrm{ha}^{-1}\right)$

\begin{tabular}{lc}
\hline Application intervals (Weeks) & Yield $\left(\mathrm{tha}^{-1}\right)$ \\
\hline 1 & 3.6 \\
2 & 3.5 \\
4 & 2.7 \\
Control & 2.5 \\
SED $(\mathrm{P}<0.05)$ & 0.4 \\
\hline
\end{tabular}

TABLE 3. Benefit-cost ratio of applying Ridomil Plus 66 WP to manage taro leaf blight disease

\begin{tabular}{|c|c|c|c|c|}
\hline \multirow[t]{2}{*}{ Variables } & \multicolumn{4}{|c|}{ Weekly spraying intervals } \\
\hline & 1 week & 2 weeks & 4 weeks & No spraying \\
\hline Yield $\left(\mathrm{t} \mathrm{ha}^{-1}\right)$ & 3.30 & 3.20 & 2.40 & 2.20 \\
\hline $\operatorname{Price}(\phi / t)$ & 500.00 & 500.00 & 500.00 & 500.00 \\
\hline Total revenue & $1,650.00$ & $1,600.00$ & $1,200.00$ & $1,100.00$ \\
\hline Total cost & 570.00 & 390.00 & 320.00 & 250.00 \\
\hline Net present value & $1,080.00$ & $1,210.00$ & 880.00 & 850.00 \\
\hline Cost-benefit ratio & 2.89 & 4.10 & 3.75 & 4.40 \\
\hline
\end{tabular}


and 4 weeks spray intervals, respectively. However, non application of fungicide (control) recorded the lowest cost and revenue, and recorded the highest benefit-cost ratio of 4.4 (Table 3 ).

\section{DISCUSSION}

The study demonstrated that spraying intervals can influence efficacy of Ridomil Plus 66 WP for the management of taro leaf blight disease caused by $P$. colocasiae. Irrespective of the application interval used, it was observed that disease incidence and severity reduced; while a higher yield was obtained compared to the control plots. The efficacy of Ridomil Plus 66 WP in controlling taro leaf blight disease was highest when applied at weekly intervals, but less effective when applied at four weekly spray intervals. The influence of spraying frequencies on the efficacy of fungicides for the control of plant diseases as observed corresponds with Tarla et al. (2014), Omeje et al. (2015) and Manju et al. (2017) who found significant effects of fungicide spraying frequencies on taro leaf blight disease incidence and severity reduction. Yield of taro was large in weekly fungicide application. Applying fungicides, according to Baibakova et al. (2019), inhibits rapid development of fungal pathogens, thereby reducing their ability to cause severe tissue damage which invariably increases leaf surface area for efficient photosynthesis. The insignificant difference in taro corm yield recorded on plots treated with Ridomil Plus 66 WP at weekly and biweekly application intervals could be attributed to the low disease severity observed following frequent fungicide application which inhibited spread of the disease on the photosynthetic area. Metalaxyl based compounds such as Ridomil Plus 66 WP, according to Mazakova et al. (2011), act on the pathogen by inhibiting mycelial growth, haustorium formation and sporulation, thereby suppressing growth and infectivity on their host. Applying Ridomil Plus $66 \mathrm{WP}$ was found to be beneficial as each of the application intervals used recorded higher revenue and net present value compared to no fungicide application. Ridomil Plus 66 WP every two weeks was more economically efficient as it recorded the highest net present value, contradicting Tarla et al. (2014) who found that application of Plantomil at four weeks interval was more economically beneficial than two weeks spraying interval. Singh et al. (2012), however, argued that the quantity and frequency of application of fungicides for disease control under epidemic condition, makes chemicals treatments in taro leaf blight disease management not economically sustainable. Non-application of fungicides during disease outbreak may, however, not be prudent to leave farms untreated as the epidemic can greatly affect yield which can lead to food insecurity and affect livelihood of farmers.

\section{CONCLUSION}

It is advisable to judiciously apply Ridomil Plus $66 \mathrm{WP}$ at two weekly interval to reduce taro leaf blight disease spread and obtain appreciable yields in taro varieties susceptible to the taro leaf blight disease. In the present study, a single fungicide with the same concentration was applied at different intervals. Further works using different fungicides and at varied concentrations will be necessary to determine their potential in managing leaf blight disease of taro.

\section{ACKNOWLEDGEMENT}

Authors acknowledge technical assistance of Rose Baafi, Maxwell Kwodane and Bismark Abugri of CSIR-Crops Research Institute and Agnes Nti, a taro farmer at Kwamo in the Ejisu Municipality. The study was conducted with funding from the West Africa Agricultural Productivity Programme (WAAPP).

\section{REFERENCES}

Adjei-Gyapong, T. and Asiamah, R.D. 2000. The interim Ghana soil classification 
system and its relation with the World Reference Base for Soil Resources. FAO Report on Soil Resources No. 98.

Amekudzi, L.K., Yamba, E.I., Preko, K., Asare, E.O., Aryee, J., Baidu, M., Codjoe, S.N. 2015. Variabilities in rainfall onset, cessation and length of rainy season for the various Agro-Ecological Zones of Ghana. Climate 3:416-434.

Baibakova, E.V., Nefedjeva, E.E., SuskaMalawska, M., Wilk, M., Sevriukova, G.A. and Zheltobriukhov, V.F. 2019. Modern fungicides: Mechanisms of action, fungal resistance and phytotoxic effects. Annual Research \& Review in Biology 32(3):1-16. https://doi.org/10.9734/arrb/2019/ v32i330083.

Gadre, U. and Joshi, M. 2003. Influence of weather factors on the incidence of leaf blight of Colocasia. Annals of Plant Protection Sciences 11(1):168-170.

Manju, E., Fokunang, C., Mbong, G., Tima, T., Suh, C., Tembe-Fokunang, E. and Hanna, R. 2017. Impact of fungicide application on taro leaf blight disease in three regions of Cameroon. Journal of Experimental Agriculture International 17(4):1-23.

Mazakova, J., Zouhar, M., Ryšanek, P., Táborský, V., Hausvater, E., and Dole•al, P. 2011. Sensitivity to fungicides in the isolates of Phytophthora infestans (Mont.) de Bary in the Czech Republic from 2003 to 2008. Plant Protection Science 47(1):512.

Misra, R.S., Sharma, K. and Mishra, A.K. 2008. Phytophthora leaf blight of Taro (Colocasia esculenta): a review. Asian Australasian Journal of Plant Science and Biotechnology 2:55-63.

Nath, V.S., Senthil, M., Hegde, V.M., Jeeva, M.L., Misra, R.S., Veena, S.S. and Raj, M. 2013. Genetic diversity of Phytophthora colocasiae isolates in India based on AFLP analysis. 3 Biotech 3(4):297305 .
Nelson, S., Brooks, F. and Teves, G. 2011. Taro leaf blight in Hawaii. Plant Disease Bulletin No. PD-71. University of Hawaii Manoa, HI, USA.

Omeje, T.E., Ugwuoke, K.I., Aba, S.C., Eze, S.C., Ogwulumba, S.I. and Ezema, R.A. 2015. Field management of Phytophthora blight disease of cocoyam (Colocasia esculenta L.) with spray regimes of selected fungicides in Nsukka, South Eastern Nigeria. Journal of Tropical Agriculture, Food, Environment and Extension 14(2):36-45.

Shaner, G., and Finney, R. 1977. The effect of nitrogen fertilization on the expression of slow-mildewing resistance in Knox wheat. Phytopathology 67(8):1051-1056.

Shively, G. and Galopin, M. 2013. An overview of benefit-cost analysis. Accessed online at http://www. agecon. purdue. edu/staff/ shively/COURSES/AGEC406/reviews/bca. htm.

Singh, D., Guaf, J., Okpul, T., Wiles, G. and Hunter, D. 2006. Taro (Colocasia esculenta) variety release recommendations for Papua New Guinea based on multi location trials. New Zealand Journal of Crop and Horticultural Science 34(2):163171.

Singh, D., Jackson, G., Hunter, D., Fullerton, R., Lebot, V., Taylor, M., Iosefa, T., Okpul, T. and Tyson, J. 2012. Taro leaf blight: A threat to food security. Agriculture 2:182203. doi: 10.3390/agriculture2030182.

Tarla, D., Fon, D., Takumbo, E. and Fontem, D. 2014. Economic evaluation of fungicide application on taro (Colocasia esculenta) leaf blight. Journal of Experiment Biology and Agricultural Science 2:2-5.

Tarla, D., Bikomo, M., Takumbo, E., Voufo, G. and Fontem, D. 2017. Climate change and sustainable management of taro (Colocasia esculenta (L.) Schott.) leaf blight in Western Highlands of Cameroon. Revue Scientifique et Technique Forêt et Environnement du Bassin du CongoRIFFEAC 6:10-19. 